\title{
THE IMPACT OF THE ELECTORAL SYSTEM ON THE PARTY SYSTEM-THE CASE OF KOSOVO
}

\author{
Valon Krasniqi, PhD \\ South East European University \\ Pristina/Kosovo \\ Valonkrasniqi6@gmail.com
}

\begin{abstract}
This paper analyses the impact of the electoral system on the party system and political stability in Kosovo. Because of the particular socio-political circumstances in Kosovo, and the post war situation, the transition and the process of democratic institution building was slow and conditioned by the rules of an international administration. After the independence of Kosovo (2008) the United Nation Mission in Kosovo (UNMIK) heritage continues to have an impact on the political system of Kosovo. The party system continues to be unstable, both in the ideological sense and in the formation of post-election governments. The Proportional Representation (PR) electoral system with a single, multi-member electoral constituency and reserved seats (20) for minorities in parliament makes impossible to have a stable majority in Kosovo. The main hypothesis of the paper is: The Proportional Representation (PR) electoral systems in Kosovo, for the period of analysis between 2001 and 2017 has a direct impact on the party system, to have an unstable multiparty system. The article uses techniques of qualitative methodology to explore the consequences of the electoral system on the party system in Kosovo, before and after its independence. The conclusions argue that that Kosovo has an unstable party system that negatively impacts on the country's governance system. Based on the findings, the article argues that there is a need for specific changes in Kosovo's electoral system in order to have a stable political party system, which will result also in a stable government. We propose changes of the electoral
\end{abstract}


system in Kosovo, from one Multi-Member Constituency (MMC), to be divided into $7+1$ constituency for minorities, in order to have a stable party system, thereby more efficient and durable government.

\section{Keywords}

Electoral System, Government, International Administration, Kosovo, Party System, Stability

\section{INTRODUCTION}

Electoral systems and party systems are linked to each other. Some electoral systems encourage the evolution of political parties more than others do. Moreover, the type of party system that evolves is greatly influenced by the electoral system in place.

The plurality voting formula often produces a majority of seats for one party in the legislature, because a party that wins a nationwide plurality will tend to be overrepresented and hold a majority of seats in the legislature. On the other hand, electoral systems featuring Proportional Representation (PR) are associated with more "proportional" vote-to-seat conversions than in plurality systems.

Political parties are the foundation of the functioning of a state in a democratic way. Political parties in Kosovo are young in terms of operation. Their development as well as the electoral rules are associated with political developments in the country, but not only.

Initially, following the collapse of communism all over Europe, political parties were also founded in Kosovo. Because of political situation in Kosovo, their functioning was more specific compared to other countries.

At the beginning of the 1990s, Eastern European countries switched to party pluralism, while the Kosovo political status known as autonomy was abolished by the Milosevic regime and Kosovo was settled under Serbian rule against the will of the people $(90 \%)$ of Kosovo. 
During such time of the Serbian rule against the will of the majority people of Kosovo, it was impossible for the political parties in Kosovo to have a normal way of functioning and behaviour. The political life was developed in parallel. The Serbia's institutions were not accepted by the Kosovo Albanians. The Albanian majority did not take part in Serbian institutional and political activities.

Following the war for the independence of Kosovo by the Albanians, as well as the NATO intervention against Serbia in 1999, Kosovo was set under International Administration called UNMIK (United Nation Mission in Kosovo). Thus, the Serbian forces and its entire administration were forced to leave Kosovo. After the liberation of Kosovo, the political parties that functioned during the 'occupation' continued their party activities. The main party was the Democratic League of Kosovo (LDK), which during 1990s stood for the rights of Albanians through a peaceful path. Likewise, new parties emerged from the Kosovo Liberation Army (KLA), such as Democratic Party of Kosovo (PDK) and Alliance for the Future of Kosovo (AAK). As of the liberation of Kosovo in June 1999 until the fall of 2000, when the first local elections and the later parliamentary elections were held, the UNMIK was the final authority in Kosovo. By the Provisional Administrative Council (PAC) as well as the Kosovo Transit Council (KTC), mechanisms representing political parties, the UNMIK held consultations with political parties rather than having co-decision making. Following the parliamentary elections, the Special Representative of the General Secretary of the UN (SRSG), through UNMIK mechanisms, determined the electoral system. In this process, the UNMIK was interested without any haste in establishing institutions elected from the will of the people. Above all, it was of interest that the representation is comprehensive, both in terms of ethnicity (through guaranteed seats for minorities) and within an ethnicity (Albanians).The electoral system was therefore designed in that spirit, which was a pure proportional and a Single Electoral Zone System with closed lists, without a threshold and with gender guaranteed quota. This electoral system guaranteed inclusiveness for all social strata. As a result of such electoral system, a large number of political parties were represented in Parliament in all the legislatures in Kosovo, during the international administration until 2008. 
After the declaration of independence, some minor amendments were made to the electoral system. The UNMIK had transferred the competencies to the political parties represented in parliament. Today, Kosovo institutions have full powers, though the EULEX exercised some judicial and security powers. Under the new mandate, the EULEX only has monitoring and advising competences regarding the cases they were working with. On the other hand, the KFOR is in charge of border security for Kosovo, while in addition to this, according to the recent developments, Kosovo created regular armed forces, called the Kosovo Security Force, which shall defend the sovereignty and territorial integrity, of the Republic of Kosovo (Rettman 2018).

The reserved seats as well as the electoral system applying in Kosovo, despite the positive aspect in terms of comprehensive representation, have had impact on the fact that political parties are ethnic, despite the investment on establishing a multi-ethnic society. The ideological division of political parties was not a matter of discussion. Main political parties had comprehensive approaches. This happens because Kosovo is still in the developing phase. Social, economic development and political culture are at an unsatisfactory level. Based on the theoretical and practical research, made by various authors on the influence of the electoral system in the party systems (Colomer 2018); (Mershon and Shvetsova 2013) (Boix 2007) and based on the analysis made in the case of Kosovo, electoral system has had impact in party system.

Regarding the stability of governance, the ideological division of parties, number of parties and the interaction between them, the party system in Kosovo can be considered as unstable.

This paper is structured as described below. In the first part, there is a review of the literature on the electoral systems, the party system, their interconnection and the influence on governance. The second part analyses the operation of political parties and the formation of governing coalitions during international administration in Kosovo. The third part deals with elections held after the independence in Kosovo, exploring the influence of the electoral system to the party system and the country's government. 


\section{THEORETICAL FRAMEWORK}

The electoral system and political parties are concepts that are interlinked with each other. Political parties in representative democracies are fundamental to institutional functioning and representation of citizen's interests and their demands. Without political parties the representative democratic system could not function. Elections are particular mechanism and rules that are determined by political parties - to convert (translate) the will of citizens into parliamentary representation, or to elect the president in countries where the people vote directly.

The academic literature on electoral systems has shown that the 'type of electoral laws and the nature of party systems are strongly correlated with each other (Duverger 1954; Taagepera and Shugart1989; Cox 1997). Plurality and majority rules come hand in hand with two-party systems. On the other hand, proportional representation laws tend to generate multiparty systems' (Boix 2007, 518-520).

However, we all know, at least since Duverger (1951), that the rules under which elections are held, particularly the rules for aggregating votes into legislative seats, affect both party systems and policy outcomes. The major contrast has traditionally been drawn between PR rules aiming to match overall vote and seat shares, and single-member constituency (usually plurality) systems more concerned with producing a definite election outcome (Budge 2007, 168-179)

It can be expected that- almost by definition- that electoral systems which are more proportional should coincide with more fragmented party systems. In the 1950's the French political scientist, Maurice Duverger (1954), put forward the proposition that non proportional electoral systems (he referred specifically to FPTP) 'favors' two-party systems, while proportional electoral systems are more appropriate for multi-party systems (Farell 1998, 149-150).

The translation of citizen interests into government policy may be far from smooth or simple, however, and this transmission is also dependent on institutions and parties. For example, the rules that govern the translation of votes into legislative seats directly affect pathways of representation. The 
discussion over the effects of electoral systems on political representation has continued (Hoag and Hallet 1926; Hermens 1941; Duverger 1954; Rae 1967; Riker 1982; Cox 1990, 1997) however, for dissenting opinions on the overstated impact of electoral systems, see Grumm 1958; Lipset and Rokkan 1967 (Ezrov 2010, 3).

As many scholars in political science have long argued, a crucial choice in building political democracy is the design of electoral systems. Indeed, given that elections are central to the functioning of democratic systems, scholars have sought to understand why different electoral systems are chosen and the impact those choices have on a range of political outcomes, both at the individual and the system level. These outcomes include the quality and breadth of representation, the fractionalization and polarization of political party systems, voter turnout and voting behaviour, and the stability of government and the political system. The scholarly work on the effects of electoral systems has focused on the longstanding debate between what is the "best" type of electoral system and a) the relationship between electoral rules and the ideological polarization and size of political party systems, b) the tendency of electoral systems to impact voter turnout and citizen participation and c) the potential for electoral systems to affect the course of democratic development. In terms of electoral formula, there is a distinction between plurality, majority, and proportional representation formula (Ishiyama 2011, 157-165).

Modern electoral democracy, broadly speaking, can take two forms: majoritarian, in which the party or coalition that wins a majority (and sometimes a mere plurality) of the vote in a popular election holds political power, or consociational, in which power sharing among a society's established ethnic groups is achieved through reserved seats for minorities in the cabinet, the parliament, and the civil service. The five differences on the executives-parties dimension are as follows: 1. Concentration of executive power in single-party majority cabinets versus executive power-sharing in broad multiparty coalitions. 2. Executive-legislative relationships in which the executive is dominant versus executive-legislative balance of power. 3. Two-party versus multiparty systems. 4. Majoritarian and disproportional electoral systems versus proportional representation. 5. Pluralist interest group systems with free-for-all competition 
among groups versus coordinated and "corporatist" interest group systems aimed at compromise and concentration (Lijphart 1999, 2-8).

Some electoral systems encourage the evolution of political parties more than others. Also, the type of party system that evolves is greatly influenced by the electoral system in place.

The difference in outcome of electoral systems can be attributed to four differences from plurality systems based on formula, district magnitude, candidate versus party voting and effective thresholds... Plurality systems will almost automatically be associated with single-member districts, individual candidates, and high effective electoral thresholds. In contrast, PR systems are associated with multimember districts, party lists, and relatively low effective thresholds. PR systems are more prevalent in developed democracies than are plurality systems. It is assumed that this happens because these systems are considered more appealing in terms of their "representativeness", than plurality systems. More parties and smaller or minority interests can gain representation in the legislature in a way that is commensurate with their level of popular support. However, critics argue that PR allows too many parties to gain power, which affects the efficiency, stability, and accountability of policy making. A more serious objection that is often raised against PR systems is that they present the opportunity for extremist factions to gain too much influence (Ezrov 2010, 8-9).

In this regard, in an extreme pluralistic system, the need for coalition governments sometimes forces parties to cooperate with tiny extremist parties in order to form a majority. PR systems can also offer an opening to extremist parties, because they, as all small parties, get a disproportionately large amount of power when larger parties need their support in order to form a government. Just as electoral system choice will affect the way in which the political party system develops, the political party system in place affects the evolution of the electoral system (The Effect of Electoral System on Party System 2012); (Katz 1980, 1-35); (Baken 2008).

Electoral system has a significant impact in party system, number of parties, governance and stability as well. There is not a magical formula of the electoral system that determines stability of party and government system. This also 
depends on other factors which are considered situational elements such as cultural, ethnic, emancipatory, historical and social elements.

Democratic Party systems do not come into being overnight but typically require extensive periods of learning on the part of electorates and politicians (Diamond 2001, 306). Political parties, their way of functioning, political programs, ideologies and their structure are very much studied by many social and political scientist. Some of which are most know and have managed to be quite influential in the field include: Giovani Sartori (1998), Maurice Duverger (1954), Daniel-Louis Seiler (2012), Gunther and Diamond (2003), Kitschelt (1995). Also Dommet (2014), Millard (2004), Web and White (2007), Lewis (2001) for political parties after the fall of the communist regimes as part of new democracies (V. Krasniqi 2016 a, 109).Whereas, parties in general, including the differences and commonalities between them, co-operation, number of parties, ideology that they represent etc., constitute the structure which is well known as a party system.

Party systems can be classified based on a number of principles, but four main classificatory schemes have been usually used: the ideologies of the parties; the extent to which parties penetrate into society; the stance of parties towards the legitimacy of the regime; and the number of parties in the system. One major recent study has sought to analyse post-communist party systems with respect to the quality of the democratic process they sustain, primarily on the basis of processes occurring in the electoral arena of party competition and voter representation (Lewis 2001, 123); (Ware 1996, 149).

Diamond, Linz and Lipset's concluded that "a system of two or a few parties, with broad social and ideological bases, may be conducive to stable democracy" to strengthening parties and remodeling party systems through the use of institutional incentives and constraints. The first approach attempts to constrain the development of ethnic parties by cross-national party formation rules that require parties to demonstrate a broad organizational base. The second attempts to use the design of electoral rules to reshape the party system. The third tries to strengthen parties from the top down, via measures to build greater internal party capacity and discipline in parliament. The final approach involves 
international interventions to assist parties in post-conflict democracies (Reilly 2008, 9-11).

In this paper, the party system will be treated in terms of the influence of the electoral system on the number of political parties, their survival, electoral thresholds, seats reserved for minorities, government stability during and after international administration and its impact in the stability of Government.

Traditionally political scientists have been very much preoccupied with the number of parties, because this number was considered important and very influential in the structure of the party system. Since the late 1960's it has become customary to describe the format of a party system in terms of the number of parties as well as the distribution of party strength within it. Scholars who examined party system polarization have been focused on Sartori's (1976) notion of left-right polarization. According to him party systems are 'bipolar' if support revolves around two poles in the left-right scale, regardless the number of parties involved, and 'multi-polar' if support pivots upon more than two poles. The number of poles depends upon the ideological distance between poles. 'Left-right polarization', then, essentially maps the level of support for political parties at various points along the left-right continuum. Electoral volatility is the propensity for individuals to vote for different parties at successive elections (Maor 1997, 28-29).

Further, Sartori makes the classification of political party system, suggesting seven classes, indicated as follows: 1) one party 2) hegemonic party 3) predominant party 4) two party 5) limited pluralism 6) extreme pluralism and 7) atomized (Sartori 2005, 110). When the party system becomes more fragmented, the electoral system will become more proportional as a consequence of the fact that a) smaller parties, which will benefit from more proportional rules, are increasingly empowered and in position of pushing for such reforms and b) larger parties usually advantaged by more majoritarian (or stronger) electoral systems faces increasing uncertainty about their future fortunes. Conversely, when the number of parties is decreasing, the gains enjoyed by the winning parties are likely to translate into majoritarian reforms to further consolidate their position (Baken 2008, 7-8). 
The number of parliamentary parties that appear to be viable contenders for government has long been used as the major principle of classification of party systems, and leads directly to the well-known and easily grasped identification of one-party, two-party and multiparty systems. But it is not just numbers that are at issue. Party systems can be seen primarily as structures of party competition and co-operation, and it is the capacity of different sets of parties to perform these functions with a view to government formation and political rule that is particularly important (Lewis 2001, 125-126). The number of parliamentary parties is often seen as central to the characterization of a party system, not only because of the fact that their number determines their potential interaction streams. Generally there are three ways to count the number of parliamentary parties. The first method is simply to count how many entities gained seats at an election. Yet we have noted that in post-communist elections not all competitors were necessarily political parties. The second method, associated with Sartori's work on party systems, is to count only those parties deemed 'relevant'. Thirdly, as parliamentary terms progressed, the unpopularity of governments increased the attractions of leaving a foundering (Millard 2004, 129-138).

Another division about the ideological positioning of political parties is the niche and mainstream parties. Niche parties refer to those parties that occupy the extreme Left, the extreme Right, or a distinctly non centrist niche; specifically, these parties belong to the Communist, Right-wing Nationalist, and Green party families. Mainstream parties are defined as parties belonging to the Social Democratic, Liberal, Christian Democratic, and Conservative party families (Ezrov 2010, 4), for more see: Mayer (2015). Ezrov (2010) finds that proportional electoral systems promote greater numbers of niche parties and their combined vote share via their impact on party system size (Ezrov 2010, 67$81)$. 


\subsection{Electoral systems in new democracies}

The influence of the electoral system on the party system is evident. The fall of communism and the process of transition to a democratic system of countries in Europe have been accompanied by many challenges and difficulties. One of the main challenges was (and in some countries still remains) definition of the electoral system and then operating within a multi-party system. In addition to this, Party systems and their stabilization nevertheless seem to play an important role in the consolidation of all new democracies (Lewis 2001, 124). Party systems in post-communist states have been especially fluid, as indicated by high rates of electoral volatility and system fragmentation. There is evidence from various regions of the world that newly competitive regimes turn to reforms of election rules more frequently than do regimes in mature democracies. However, in the face of political fluidity and transition complexity, the reform impulse is subject to two distinct pulls. On the one hand, political entrepreneurs seek to revise electoral laws toward more relaxed rules that maximize access to the party system and enhance the prospects of survival in the political game. On the other hand, a fragmented, volatile electoral environment calls for more restrictive measures that trim party systems to provide better opportunities for stable and effective political rule. Three theoretical perspectives address this issue. 1) Strategic calculations 2) governance norms; 3) institutional inertia. Thus, higher party system fragmentation leads to the probability of more permissive rules, while lower fragmentation tends toward the initiation of more restrictive electoral rules (Bielasiak 2013, 2-5).

One of the most interesting arguments in favor of the use of proportional representation is made by advocates of the consociational school, who have long argued that by promoting the emergence of ethnic politics and then representing groups broadly, this will facilitate the integration of as many subcultures as possible into the political game, thus creating the conditions for inter-ethnic cooperation. Indeed, by securing representation for minority groups, a rule such as PR serves to facilitate the integration of groups into the political system, which ultimately leads them to moderate their demands. However, there has 
been considerable debate whether the PR list systems in fact "freeze" ethnic cleavages and promote the development of ethnic parties, which Donald Horowitz (1985) views as fundamentally inimical to the development of democracy (Ishiyama 2011, 170-171); for more see: Millard (2004, 184-251).

In terms of the interrelationship between parties and minorities, one can identify four different types of parties: 1. Mono ethnic Parties 2. Ethnic Parties with Minority Candidates 3. Diversity-sensitive civic parties 4. Multiethnic parties in order to classify parties effectively, one needs to consider the programmatic orientation, the leadership and candidates of the parties, as well as the members and voters of the party (Biberaj 2008, 11-16).

To use the electoral system to try to refashion the party system, there are several ways of doing this. One of the most common is to dictate the ethnic composition of party lists. In some countries, this has enabled a more deliberate strategy of multi-ethnicity than would have been possible otherwise. Another approach has been to use technical electoral barriers such as vote thresholds, which prevent the election of many small parties to parliament. Other electoral system innovations can be used to counter party fractionalization and encourage interparty cooperation and coalition. Electoral systems can also be engineered to increase the proportion of women in parliament, via explicit gender quotas or more informal party quotas. Both approaches have become increasingly common in recent years. Legal quotas to mandate minimum levels of women's representation are widely perceived to be the quickest way to rectify the problem of under-representation. A final approach to political party engineering has been for external actors to attempt to intervene directly in the development of party systems in new or transitional democracies. This often involves channeling technical or financial assistance from international donor agencies, nongovernmental organizations or multilateral agencies to party organizations in states where the international community has taken a prominent role, such as countries emerging from a period of violent conflict. Building coherent party systems in such post-conflict societies is particularly difficult, because parties often form around the very same cleavages that provoked the original fighting, leading to the continuation of the former conflict through the electoral process. Increasing awareness of the problems of polarized or otherwise dysfunctional 
party systems created by this process has lately spurred multilateral bodies such as the United Nations - which have traditionally been wary of direct involvement in party politics, preferring more traditional kinds of development assistance - to take more active role in assisting political party development in some post conflict countries (Reilly 2008, 13-17); (Millard 2004, 85).

The election systems of the region ${ }^{1}$ share a number of features. In designing their electoral systems, most countries opted for proportional representation (PR), either with their first multi-party elections or by later shifting from mixed or majoritarian systems to PR. Thus, by 2008, among 9 countries in Southeastern Europe, only Albania has a mixed electoral system; all other countries vote by PR (Biberaj 2008, 17-18). In Bosnia and Herzegovina the grounds for elections and the electoral system have been arranged by the Dayton Peace Accords for and the Electoral Law of Bosnia and Herzegovina. The aim of the Electoral Law was to favor in the electoral competition non - nationalist parties that have multiethnic leadership and membership (Sahadžić 2009). In Croatia, the Hrvatski Sabor (parliament) comprises around 150 Members of Parliament (MPs). MPs are elected every four years by a proportional system within 10 constituencies each of these electing 14 people. The 11th constituency, comprises Croatians living abroad and the 12th constituency appoints the MPs representing the national minorities, 8 in all (Joannin 2016).

While in a case where a state or territory is under international administration with unspecified political status, the case with Kosovo was from 1999 till 2008, the role of the international administration is decisive in defining the electoral rules and supporting political parties, either directly or indirectly.

Depending on the context, the past, the social, ethnic, regional composition, the number of population, size of territory, determination for one or other system is crucial in representing the citizens. While the international administration aims to establish a system that produces a comprehensive result (V. Krasniqi 2016b). According to Brahimi, "the election and the electoral system is very important during the peace building process. While holding the election is key element, the

${ }_{1}$ Albania, Bulgaria, Macedonia, Kosovo, Montenegro, Serbia and Romania. 
rush to equate democracy with the elections risks, confusing the goal and process with the mechanism, often leads to a relapse into conflict. While the political momentum generated by a peace agreement or by the fall of an authoritarian regime can create pressure for elections to take place quickly, voting that takes place too soon after the end of conflict may well reinforce existing divisions and fault lines rather than create new bonds to promote mutual trust and cooperation. Moreover, hurried balloting will not necessarily favor progressive, moderate forces that are so critical to the maintenance of peace as these parties do not have sufficient time to raise the economic resources necessary to become competitive (Brahimi 2007, 10-12).

The international administration to set the rule and representation of social structures takes care that through legal mechanisms to support or impose certain rules, which in other cases may not be decided without outside imposition.

In 8 of the 17 countries (including Kosovo) in Central and South Eastern Europe, special mechanisms are in place to secure and facilitate the representation of minorities in parliament. In particular, all the countries of former Yugoslavia (with the exception of Macedonia) have some means of promoting the parliamentary representation of minorities. This trend is partly a reflection of the conflicts in the 1990's, but more a continuation of the elaborate institutionalization of ethnic representation that took place under communism (Reilly 2008, 114).

Beyond party systems effects and effects on voter behaviour, there is also evidence that the type of electoral system can impact the political opportunities for women and minorities as well (Rule 1994). According to Chesterman, proportional representation quotas should remove the need to ensure ethnic representation, but quotas are used in some cases to ensure female gender representation in political processes. Women's involvement in areas such as peace building and the security sector is widely acceptable (Chesterman 2004, 216-217).

Also according to Caplan, it is important to determine the rules of elections for the political system. Thus, defining a majority, mixed or proportional system in a country, especially under international administration, is quite challenging for 
the country's governance. According to him, the international administration is interested in stability, while this is achieved more easily through the support of moderate candidates and parties, which are also supported by the international administration. Support is financial and for public promotion. While in the final, the international administration supports and defines that electoral system that they think would produce favorable results for them (Caplan 2005, 126-129).

In general, parliaments elected under proportional electoral systems tend to be more representative of society than is the case for those parliaments elected under non-proportional systems. This can also be seen in terms of the number of parties in the parliament and in the representation of women. While few would dispute that having a more representative assembly is a good thing, there is considerable dispute over the degree to which such an assembly can operate effectively.

\section{ELECTIONS AND PARTY SYSTEM IN KOSOVO DURING THE INTERNATIONAL ADMINISTRATION}

The Political and Party system in Kosovo has its own specifications. While during 90's, the former communist countries started to act under democratic and pluralist party system, Kosovo was set under the Serbian 'occupation' (Judah 2008, 64-75). During this time in Kosovo, some political parties like LDK were allowed to act, which was more like Kosovo Albanians movement against Serbian rules than it was a political party in a classic way. Kosovo, during 19891999, continued its resistance against Serbian regime, by not accepting that system through developing of a parallel institutional life in all fields.

During the 1990s, more than one political party were operating in Kosovo - the Democratic League of Kosovo, the Social Democratic Party of Kosovo, the Kosovo Parliamentary Party, the Democristian Party and the Liberal Party, were some of the parties that existed before the war - however, they did not operate in an environment that allowed normal development of political life and democracy (Krasniqi and Shala 2012, 8-9). 
During the time of conquest until 1999, it was impossible to talk about ideological profiling or defining certain development and orientation. The whole orientation was for survival, liberation and independence of the country from Serbia. In this period, Kosovo led by LDK pursued peaceful politics while other countries of the former Yugoslavia like Croatia and Bosnia were in war with Serbia. Consequently, Kosovo was excluded from the processes that were taking place such as the Dayton peace agreement. This was a turning point to understand that without war, independence could not be achieved.

With the development of fighting between the Serbian armed forces and the KLA (Kosovo Liberation Army), which had emerged from the people of Kosovo, violence by the Milosevic regime dramatically increased.

The NATO alliance, after some unsuccessful attempts to achieve an agreement with Milosevic, started the bombing campaign of Serbia that lasted for 78 days. After the end of the bombing, Serbia was forced out of Kosovo. The UN issued 1244/1999 Resolution and ordered the deployment of the International Administration to Kosovo, named UNMIK.

The LDK (led by Ibrahim Rugova) was the main political party during the 1990s. Some young people, but not only, were convinced that freedom could not be achieved without war. As a result they founded the Kosovo Liberation Army. For more see (Judah 2008, 75-92). After the war, two significant political parties were founded from the people who had senior commanding positions and directing positions in the KLA. They are PDK (led by Hashim Thaci) and AAK (led by Ramush Haradinaj).This was the moment when LDK was expected to have serious electoral competition, because before the war it predominated alone. The latter can be considered more as a popular movement than it was a political party. Today these political parties and VV (Self-Determination led by Albin Kurti) are the main parties in terms of people support.

During the International Administration the relationship between political parties was quite tough and unsympathetic, especially between PDK and LDK. Whereas non-majority communities were not involved in this rivalry.

No political party in Kosovo refused democratic values, though they did not have any concerns about democratic commitment. 
In several aspects, local stakeholders (political parties) and international stakeholders (UNMIK and Embassies) pursued competitive objectives, whereas co-operation has largely been good. In addition to this, in some cases, the SRSG intervened, especially as far as some political-social entities were concerned. Therefore, the locals and the UNMIK generally had more agreements than objections, thus applying their international influence. (For more information concerning the period 1989-1999, respectively, the peaceful orientation of the LDK as well as the Kosovo Liberation Army (UCK), see: Caplan (2005, 133-146); Lindsey $(2009,10-13)$, as well as Tansey $(2009,110-117)$.

The foundation of political parties in Kosovo was influenced by political and historical circumstances, excluding the ideological model of party establishment. International protectorate, the lack of political status definition and relations with Serbia, have largely determined the direction of political parties in Kosovo. In terms of clarifying the political party relations with ideology, some of the reasons that negatively affected the failure of ideological profiling of the parties were the following phrases: Freedom, Independence, and Democracy. Moreover, the main topics addressed by the political parties were: membership with the NATO and the EU, economic development, decrease of unemployment, the rule of law. As a result, parties within themselves in Kosovo vary from left to right spectrum (Hofmeister 2011, 102-103).

The party system in Kosovo during the international administration in terms of decision-making as well as the determination of the rules of functioning and the holding of elections was limited. Political parties in Kosovo had limited competences because the real power were exercised by the UNMIK.

The UNMIK had the main role in establishing the legal basis, the circumstances and the political setting for organizing firstly the local elections and later the parliamentary elections (UNMIK 2000). Moreover, special attention was paid to reconciliation and multi-ethnic representation in institutions, which was often disproportional to the situation on the ground. As a result of commitment and the interest for inclusion and reconciliation of all communities in Kosovo, there were used mechanisms for legal protection for the minorities (V. Krasniqi 2016b, 82-85). 
Regardless of the high level of international presence and governance, as it was in Kosovo, the relation and the co-governance with locals are determinant for the success of the mission. Whereas, the best way to do it in the countries when there are no elected institutions, or when there are institutions but they lack legitimacy, is to organize elections, identify the legitimate parties and have cogovernance with them.

Apart from the rivalry between political parties, in post-war countries under international administration, such as Kosovo, it is important to understand the context and other divergences within society. If the culture is not understood in general, and the political culture in particular, taking into consideration such reality, then it is a problem to move forward and have a successful governance (V. Krasniqi 2016b, 52-53).

According to Tansey: "Political developments in Kosovo were not exclusively directed by the international community, but local stakeholders were part of the process. Local politics in Kosovo were characterized by three divisions associated with the historical and political context with Serbia, which has influenced the formation of UNMIK's internal activities and priorities. The first division exists between Albanians and Serbs, as well as the parties in Kosovo. This affected the division of opinions and actions between Albanians and Serbs. It also influenced in having ethnic parties and lacking any multi-ethnic party. Serbian participation in the processes and structures of self-government at the time of UNMIK was limited, boycotting the elections and central institutions. The second division is within the Serbian community itself, where some were against co-operation with UNMIK and Kosovo institutions, while some were in favor. And the division third was the political spectrum of Kosovo Albanians within itself, based on the history of the conflict with Serbia (Tansey 2009, 115117). 


\subsection{Parliamentary Elections during the International Administration}

During the international administration from 2000-2008 in Kosovo, regular parliamentary and local elections were held ${ }^{1}$.

The Assembly have 120 members elected by secret ballot. Kosovo shall, for the purposes of election of the Assembly, be considered a single, multi-member electoral district. (a) One hundred (100) of 120 seats of the Assembly shall be distributed amongst all parties, coalitions, citizens' initiatives, and independent candidates in proportion to the number of valid votes received by them in the election to the Assembly. (b) Twenty (20) of the 120 seats shall be reserved for the additional representation of non-Albanian Kosovo Communities ${ }^{2}$ (UNMIK 2001, 18-19).

The parliamentary elections were held in 2001, 2004 and 2007. The mandate was three years. The legal basis and the electoral system was defined by the The Special Representative of the Secretary-General (SRGS) (UNMIK 2001). The electoral system in Kosovo was proportional, single constituency, with closed list in 2001 and 2004 elections. Whereas in the 2007 elections, the party's electoral lists were opened.

Kosovo is considered a single multi-member electoral district for the purpose of electing the Assembly. 'The overall number of Political Parties certification for the Parliamentary Elections in Kosovo since 2001 until today was: In 2001: 39, 2004: 33, and 2007 (Local and Parliamentary): 96, 2010: 29. 2014: 30, 2017 (parliamentary political subjects): 13 (Central Election Commision 2017a , 38).

1In this paper the purpose of research will be the central level of power.

${ }^{2}$ As follows: Ten (10) seats shall be allocated to parties, coalitions, citizens' initiatives and independent candidates having declared themselves representing the Kosovo Serb Community. Ten (10) seats shall be allocated to other Communities as follows: the Roma, Ashkali and Egyptian Communities four (4), the Bosnian Community three (3), the Turkish Community two (2) and the Gorani Community one (1). Geographical and gender requirements in respect of candidate lists submitted by parties, coalitions and citizens' initiatives for the purpose of the election to the Assembly may be specified by the SRSG on the recommendation of the Central Election Commission. 
First Legislation Period (17.11.2001-23.11.2004) - Political Groups in the Assembly of

\begin{tabular}{|l|l|}
\hline LDK Group & Kosovo \\
\hline PDK Group & 26 seats \\
\hline AAK Group & 9 seats \\
\hline KP Group & 22 seats \\
\hline Other communities & 11 seats \\
\hline No group & \\
\hline Total & 4 seats \\
\hline
\end{tabular}

Source: Assembly of

Kosovo

In the first post-war parliamentary elections held in 2001, the party system in terms of the number of parties competing and also being part of the Parliament was multi-party system. But in the ideological aspect, there was virtually no division. Also, with the "suggestion" of the International Administration (UNMIK) in order to have stability, main parliamentary political parties were part of government. The main political parties were in government, the LDK, PDK and AAK ${ }^{1}$. Thus, there was an inclusive government, without opposition parties. For the principle of democracy, the lack of opposition parties can be considered as non-democratic, but as we have said above, the international administration was concerned about stability, especially in the post-conflict

1Political parties representing the minorities in Kosovo, so far in 2018, have been continuously part of the government. There were time periods, especially after the war, when Serbian parties did not participate in the government. 
phase. Also based on the number of seats won by the parties in the elections, no party could have a simple majority. This happened at least for two reasons. The first reason was because of the PR electoral system, wherein electoral system enabled many political parties to be a parliamentary party, even with formal support. The second reason was due to reserved seats, wherein out of 120, all parties ran only for 100 seats, including also minorities. 20 seats were guaranteed, 10 for the Serb community and 10 for other non-majority and nonSerb communities. According to the election results of 2001, because of the electoral formula, 22 seats were taken only by Serbs, and 11 by other communities. In addition to the guaranteed seats for minorities, political parties in their electoral lists were obliged to put every third candidate in the list a female, which makes up 30 percent of the representatives. All these combinations resulted in sustainable governance due to the UNMIK's great impact, but without any concrete results in terms of economic development. The orientation was in the re-establishment of Kosovo in all respects.

Whereas, only after the second parliamentary elections held in 2004, the principle of opposition was established. LDK, AAK and Minorities were in the Government, PDK and a new established party called ORA were in the opposition. The electoral system was the same as in 2001 and also the party system in terms of numbers was quite fragile with eight parliamentary groups. The characteristic of this legislature was the division of the LDK into two groups after the death of President Rugova, and the formation of the new parliamentary group called LDD (Democratic League of Dardania, led by Nexhat Daci).

Second Legislation Period (23.11.2004-12.12.2007) - Political Groups at the Assembly of $\underline{\text { Kosovo }}$

\begin{tabular}{|c|c|}
\hline LDK Group & 44 seats \\
\hline PDK Group & 30 seats \\
\hline AAK Group & 11 seats \\
\hline
\end{tabular}




\begin{tabular}{|c|c|}
\hline ORA Group & 7 Seats \\
\hline SLKM-Gis Group & 8 seats \\
\hline GP 6+ Group & 6 seats \\
\hline Group for Integration & 6 seats \\
\hline No Group & 3 seats \\
\hline LDD Group & 5 \\
\hline Total & 120 seats \\
\hline Source: Assembly of Kosovo & \\
\hline
\end{tabular}

At this time 2004-2007, final status talks were held. The Government in this period was stable and in 'coexistence' with UNMIK. Until the 2007 elections LDK led by Ibrahim Rugova was the main political party. While PDK led by Hashim Thaci, as the main opposition party with 30 seats, had been co-operating with the Government during the final status talks in Vienna.

In 2007, the electoral system was the same with the exception of opening lists and voting for 10 candidates within an electoral list, as well as setting the threshold of 5 per cent, while for parties representing national minorities, the electoral threshold does not apply (UNMIK 2007).

Comparing with previous elections with closed lists, the irregularities that emerged during these elections are partially attributed to the electing up to 10 candidates on a ballot from the same political party. The large number of candidates to be voted created confusion among voters and increased the invalid number of ballots. It also enables to deviate from the will of the people. It gave the candidates from the same political party the opportunity to make arrangements for mutual support in certain regions, where they had a smaller base of voters. Despite this, the result of the elections was internationally recognized. The competencies of the interim local institutions were still limited, 
as in 2001 and 2004, but with some advances in the transfer of responsibilities by UNMIK.

The proportional representation (PR) system with a single constituency and reserved seats for minorities did not allow a single party to win the majority. As a result, Political Parties had to form coalitions after the elections. In the 2007 elections PDK won 34 seats, thus for the first time was the main party led by Hashim Thaci. But the government was again formed with the 'suggestion' of international friends between PDK and LDK with 28 seats, who at the same time were the main rivals. Minorities as usual were part of the government.

On the other hand, the opposition was weak in numbers with 31 seats represented by $A A K$ and $A K R$, which acted separately in the Assembly. AKR participated in the elections for the first time in the elections, while ORA failed to pass the election threshold. The justification for a "large" coalition between PDK and LDK, because of the number of seats and history represented by these two parties, was seen very important to make big decisions, wherein the most important one was the declaration of Kosovo independence on February 17, 2008.

Third Legislation Period (13.12.2007-03.11.2010) - Political Groups at the Assembly of $\underline{\text { Kosovo }}$

\begin{tabular}{|c|c|}
\hline PDK Group & 34 seats \\
\hline LDK Group & 28 seats \\
\hline AAK Group & 13 seats \\
\hline LDD Group & 9 Seats \\
\hline AKR Group & 9 seats \\
\hline $7+$ Group & 7 seats \\
\hline
\end{tabular}




\begin{tabular}{|c|c|}
\hline Group for Integration & 7 seats \\
\hline SLS Group & 9 seats \\
\hline NO Group & 5 \\
\hline Total & 120 seats \\
\hline Source: Assembly of Kosovo & \\
\hline \hline
\end{tabular}

Following the declaration of independence, the UNMIK's role was extensively minimized, though the UN Resolution 1244 is still in force, because Russia and to some extent China are continuing to oppose Kosovo's independence.

Until the declaration of independence, UNMIK was the actor and determining factor in decision-making. In regards to UNMIK's influence in Kosovo, a survey was conducted through a questionnaire carried out by the author with 200 respondents on UNMIK's influence on determining the Electoral System and the time of holding elections. The result of data collected by author was as follows: out of 200 respondents, 46 fully agreed, 113 agreed, 25 stated "I do not know", 13 do not agree and 3 fully do not agree (V. Krasniqi 2016b, 57-58).

The party system in Kosovo during the UNMIK administration 2001-2007 may be considered as unstable, with many political parties, either regarding the number of parties participating in the parliament (heterogeneous), or establishing of new parties and the interruption of the political activities by some of them. Moreover, the responsibilities were shared, not only by the political parties in power, but also by UNMIK. Any failure was addressed to one another, whereas any success, though successes were missing, were attributed to themselves. In terms of numbers, the government, supported by the international administration either in forming coalitions or during the governance, was stable.

The PR electoral system and one single constituency system with closed lists was designed by the UNMIK, in order to achieve three purposes. First, such system would not allow any party to win the elections alone. Second, it was an inclusive system, representing ethnic and gender groups in the Assembly. Third, 
through the closure of lists (2001/2004), the party leaders had more control and were determinant in ranking candidates in the list. By this, it was also easier for UNMIK to manage the situation. All of these elements were to guarantee stability, which was the top priority for UNMIK.

Therefore, stability and inclusion of non-majority communities and establishment of a multi-cultural environment was the purpose of the international community in Kosovo. The political parties had no program offers or substantial ideological distinctions due to the conditions of operation and the state of their initial establishment process, though they acted in circumstances being more normal compared to the period from 1990-1999.

\section{PARTY SYSTEM AND (IN) STABILITY OF POST INDEPENDENCE GOVERNANCE}

All the parliamentary elections after the independence, in 2010, 2014 and 2017, were early elections. The reasons for going into early elections have been different, which at the same time indicates the lack of stability of the party system in Kosovo.

The electoral system regulated by the Constitution and defined with the Electoral Law (2008 and Amendment 2010) continues to be applied in Kosovo. There have been minor changes compared to the election rules applicable during the International Administration.

The electoral system applied in Kosovo after the independence is a PR with a single constituency, with an open list and a threshold of 5 per cent, despite the demand of civil society to drop to three per cent (Ejupi 2011, 7). The only difference was the reduction of the voting option within a party list, from 10 to 5 (Kosovo Assembly 2010). The guaranteed seats for minorities, from 20 reserved seats plus the other that may be won, have been limited to 20. Women are represented by at least 30 percent.

The Assembly has one hundred and twenty (120) members elected by secret ballots on the basis of open lists. The seats in the Assembly are distributed 
amongst all parties, coalitions, citizens' initiatives and independent candidates in proportion to the number of valid votes received by them in the election to the Assembly (Constitutional Court of the Republic of Kosovo 2010).

With the new reality after independence, the role of political parties has been extended in terms of taking on representative and governing responsibilities. In the military aspect, NATO through KFOR continues to be present and responsible for securing the borders of Kosovo.

\subsection{Parliamentary Elections}

In the period 2007-2010, PDK and LDK governed the country. These parties have always been the main rivals. The differences between them in their programs and governance were not distinctive. In the course of their performance, the differences between PDK and LDK were so unimaginable that there were instances where there were individuals inside these parties who had more different views with the members of his/her own party than to the other. The AAK, AKR and LDD were in the opposition during 2007-2010. Also this period was the first phase of governance in Kosovo after the declaration of independence of the country (V. Krasniqi 2016 a, 112-113). During PDK-LDK's governance, they were oriented towards state-building and power retention.

\subsection{Parliamentary Elections}

The Parliamentary Elections in 2010 were early elections. Kosovo Assembly was dissolved without completing its first mandate after independence and the fourth mandate, since the liberation. This was confirmed as well after the decision of the Constitutional Court in 2010, Case nr. Kl 47/10, on violation of the Constitution following the issue of two positions held by the President of Kosovo and the President of LDK (Constitutional Court of the Republic of Kosovo 2010). After the Constitutional Court's decision, LDK left the ruling 
coalition whereby the country entered into institutional crisis and which derived holding of new parliamentary elections.

Characteristic of these elections was that Vetevendosje Movement (LV) decided to register as a political entity and to run for the election in the Assembly. This movement has been recognized as a strong political opposition in Kosovo, demonstrated through protests. Their opposition was also expressed through the damage to UNMIK vehicles and later to EULEX as a reaction of dissatisfaction with them.

Fourth Legislation Period (12.12.2010-07.05.2014)- Political Groups in the Assembly of $\underline{\mathrm{Kos} O v 0}$

\begin{tabular}{|c|c|}
\hline PDK Group & 32 seats \\
\hline LDK Group & 29 seats \\
\hline AAK Group & 13 seats \\
\hline Vetëvendosje Group & 13 Seats \\
\hline KKR Group & 8 seats \\
\hline GP 6+ Group & 6 seats \\
\hline SLS Group & 8 seats \\
\hline NO Group & 11 \\
\hline Total & 120 seats \\
\hline \multicolumn{2}{|c|}{ Source: Assembly of Kosovo } \\
\cline { 2 - 2 }
\end{tabular}

Another new party that emerged during the 2010 election was the New Spirit Party (FER). This party, was founded by two civil society members (Shpend Ahmeti and Ilir Deda). It was focused on the rule of law and the professionalism 
of its members, as the key party values. After the elections, this party was disintegrated and a part of the party joined Vetëvendosje.

Since the threshold for entering the assembly was $5 \%$ of the total votes cast for the Albanian parties, most of the smaller parties entered into coalitions with the largest parties. This increased their chances for them to enter the Assembly, as a ruling party or as an opposition. One of the biggest agreements for the preelection coalitions was that of the New Kosovo Alliance (AKR), consisting of seven political parties that did not discriminate party ideologies, and included social democrats, green parties, and right-wing conservative parties (Ejupi 2011, 7-11).

As of March 2011 until June 2014, Kosovo was governed by PDK and AKR. This ruling coalition was based more in numbers in order to create a majority in the Assembly rather than in ideological and program similarities. At the same time it was a strong opposition in numbers, but there was a lack of unity and ideological program on the side of the opposition parties (V. Krasniqi 2016 a, 112-113). The election results were close as in the previous elections. No single political party could form the government. This happened for the same reasons: The electoral system as well as reserved seats for minorities restricted the possibility of a party majority.

PDK with 32 seats and AKR with 8, plus the minorities formed the government. This government in terms of seats was very fragile. With this composition, Kosovo was governed until 2014, when the government fired itself. The country's political scene was faced with an unusual situation for a relatively long period of time. The government did not have a majority in the Assembly to approve legislation or decisions requiring an absolute majority, and on the other hand, the opposition in the Assembly did not have the numbers to demand the resignation of the government, because of fragility and lack of unity. In this context, there was an agreement between political parties that in such a situation the state could not function, so an immediate need for extraordinary elections was introduced. 


\subsection{Parliamentary Election}

The June 8, 2014 elections came as a result of the Kosovo Assembly's selfdisintegration decision, following Prime Minister Thaci's suggestion.

These elections were organized with the old electoral system. Political parties failed to reach an agreement to amend electoral legislation, although this process started in April 2011, following the adoption of the Resolution in the Kosovo Assembly. Prime Minister Thaci justified the decision to hold the new elections because of lack of functionality of the institutions, including the failure of the Assembly to establish the Armed Forces of Kosovo.

Fifth Legislation Period (17.07.2014-10.05.2017) - Political Groups at the Assembly of Kosovo

\begin{tabular}{|c|c|}
\hline PDK Group & 36 Seats \\
\hline LDK Group & 33 Seats \\
\hline AAK Group & 8 Seats \\
\hline Vetëvendosje Group & 16 Seats \\
\hline NISMA Group & 6 Seats \\
\hline GP 6+ Group & 6 Seats \\
\hline SLS Group & 11 Seats \\
\hline NO Group & 4 Seats \\
\hline Total & 120 seats \\
\hline
\end{tabular}

Source: Assembly of Kosovo 
Unlike previous years, in 2014 elections, the electoral offers of political parties was more concrete, better articulated, with a clearer vision for providing certain solutions. The offer was comprehensive, with the main focus on economic development and employment, visa liberalization to Schengen Countries and EU integration.

The official election result of the June 8th, as expected, did not bring any major change from the previous elections. The Democratic Party of Kosovo (PDK) was the first in the Kosovo Parliament with 36 seats, followed by the Democratic League (LDK) with 33, the Self-Determination Movement (LV) with 16 seats, the Alliance for the Future of Kosovo (AAK) with 8 seats and the Initiative for Kosovo (NISMA) with 6 seats. The rest of 20 seats were from the national minorities. Therefore, no political party managed to win 61 mandates, or $50+1$ percent.

Following the announcement of the election results, leaders of the Democratic League, the Alliance for the Future of Kosovo and the Kosovo Initiative signed an agreement for the establishment of the new government, bringing to the attention the right to it, due to the majority in the Parliament. Similarly, the VV joined later in order to leave PDK in the opposition. Meanwhile, the Democratic Party, who won the most seats in the election, insisted that it had the right to form the government, based on the Constitution. According to the Constitution of Kosovo (chapter four and five), the president proposes to parliament the candidate for prime minister after consulting with the political party or coalition that has won the minimum required majority in parliament to form the cabinet. If the government's proposed composition does not obtain a majority of votes in the Assembly twice, by electing another prime-minister candidate, Kosovo's president announces new elections, which must be held no later than forty days from the day of their announcement. 'A number of politicians and political analysts, including foreign diplomats, were engaged in various discussions and interpretations, which made the President of Kosovo, Atifete Jahjaga, to address the Constitutional Court with a request to clarify its role in the constitution with the formation of the government cabinet' (Gazeta Shqip 2014). This was happening because PDK failed to make a coalition with any parliamentary political party. Minorities were not declared. Following the submission of the 
case for interpretation of who was entitled to propose the President of the Assembly and as a result of the formation of the government, the Constitutional Court came to the conclusion (Case No. K0119/14) that based on the legitimacy of the people and considering the parties or coalitions before the elections for which the citizens have voted, the party or the pre-election coalition which wins the most seats in Parliament after the elections, has the right to elect the President of the Assembly (Constitutional Court of the Republic of Kosovo 2014). This gave PDK the right to be part of the government. After more than five months of holding elections, the two leaders of PDK and LDK reached an agreement to establish a new government, based on the Constitutional Court Decision.

This was the longest crisis for electing institutions, as a result of initially not reaching the majority of any party, due to the lack of ideological profiling of the political parties, but not only! In principle each party could make a coalition with other parties, because there were no substantial differences in the programs. Refusal to PDK came due to allegations of mismanagement and mistrust for it rather than dealing with program differences.

\subsection{Parliamentary election}

Early parliamentary elections followed the collapse of the LDK-PDK coalition government, after a no-confidence motion raised by opposition parties and supported by MPs of the ruling Democratic Party. One of the main reasons declared by the PDK for the support of the non- confidence motion was the lack of the decision making, like for Demarcation of the line border with Montenegro, as the precondition for visa liberalization with EU.

Early elections of 2017 were held with the same electoral system, amended for the last time in 2010. PDK, which was the largest party, ran for the first time in elections without leader Hashim Thaci, who was voted as the President of the country. Now, his successor is Kadri Veseli.

A characteristic of the 2017 elections was creating of pre-election coalitions by the parliamentary and non-parliamentary parties. Three poles competed in these 
elections, not including minorities that continue to have reserved seats. 'In total, in 2017 Parliamentary Election competed thirteen political subjects' (CEC 2018).Coalitions were neither ideological nor programmatic. More were about increasing the prospect of coming into power. Pre-election Coalitions between the parties also existed in previous elections, between one of the large parties and some parties with symbolic electoral support. Peculiarity of the recent preelection coalitions that are influenced by the Constitutional Court's decision on the right to form a government were pre-election coalitions between main political parties, like never before in Kosovo such as: PDK, AAK and NISMA (PAN Coalition) ${ }^{1}$ (CEC 2018). This coalition of the parliamentary parties can be considered natural ${ }^{2}$, based in their history, but the paradox was precisely on the fact that PDK was in power, while AAK and NISMA in opposition, who along with VV were harshly criticizing the government of PDK and LDK.

On the other hand, the Coalition LAA, consisting of LDK and two other parties, AKR which could not pass the electoral threshold in 2014, as well as the Democratic Alternative led by the former deputy Prime Minister and the Major of Gjakova, Mimoza Kusari. Vetëvendosje competed in the election solely as a political party.

The pre-electoral coalition of PDK with AAK and NISMA was a surprise. PDK had given up on government leadership, offering the post of Prime Minister to Ramush Haradinaj from AAK. PDK as the main party that was in government with the LDK was mostly criticized by AAK, inter alia because of the demarcation of the border with Montenegro, accusing PDK and LDK of giving away land due to mistakes made in determination of line border.

The election coalition of PAN was more about coming to power than for their program. This shows the negotiation not about the program between the parties

${ }^{1}$ In the list of PAN coalition were: The Party of Justice; Movement for Union; Kosovo Democratic Christian Albanian Party; Conservative Party of Kosovo; Democratic Alternative of Kosovo; Republicans of Kosovo; Balli Party; Social Democratic Party; National Balli of Kosovo.

${ }^{2}$ Despite the fact that part of this coalition were nine more none Parliamentary Political Parties. 
but first they agreed on government positions. There was also no agreement on issues that continued to be open, such as the Demarcation, which were the reason for the fall of the previous government (PDK and LDK).

These pre-election coalitions in 2017 were reached just a few hours before the legal registration date for parties or coalitions at the CEC to compete in elections. The intention of parties in coalitions was to reach at least 41 deputies (seats), plus minorities, to have the right in forming the government. But the results were far from expectations for the two pre-election coalitions. The surprise was the doubling of the VV who alone managed to win 32 mandates. The results of election complicated the possibility to establish a new government. Under these created circumstances, due to the refusal of LDK and VV to be part of any coalition with PDK, the only option for PAN remained AKR with four MPs, which party was in pre-election coalition with LDK. AKR left the LAA coalition and joined the PAN government. After certification of mandates, the PAN coalition formed separate parliamentary groups.

The PDK compared with the seats in the previous legislature, was the one losing the most of seats from the pre-election coalition. It won only 23 seats in the Assembly. This low result of PDK is considered to take place for several reasons. First, being a ruling party and having strong clientele, failed to get the support as expected. Secondly, as the main party until the parliamentary elections 2017 with 32 mandates, the candidate list was shared with AAK and NISMA. Out of 100 candidates, there were only 55 candidates from PDK in the coalition list. Not including many PDK figures on the list of candidates for MPs, affected the engagement of potential candidates during the elections.

\subsection{Government formation in 2017}

After more than two months of uncertainty and inability to establish institutions, an agreement was reached between PAN (PDK, AAK NISMA), $\mathrm{AKR}$, and the Serbian List with $9 \mathrm{MPs}$, one MP from the Serb community was not part of the Serbian list and 10 MPs from the non-majority and non-Serb community. This coalition is very unstable in terms of numbers with only $62+1$ 
seats.The Serbian List contributes to the instability of the government, as based on the previous experience it consults Belgrade on important decisions and not rarely it blackmails the processes in the Assembly. This took place also when voting for the government, wherein voting of the government had to be postponed for several hours waiting for the Serbian List to come from Belgrade, where they were for instructions from the Serbian Government. On the other hand, the opposition composed of VV and LDK, regardless of the lack of unity, is powerful.

Sixth Legislation Period (17.07.2017-Continues) - Political Groups in the Assembly of $\underline{\text { Kosovo }}$

\begin{tabular}{|c|l|}
\hline PDK Group & 23 seats \\
\hline LDK Group & 27 seats \\
\hline AAK Group & 10 seats \\
\hline Self-determination Group & 32 Seats \\
\hline Serbian list Group & 9 seats \\
\hline Initiative for Kosovo Group & 6 seats \\
\hline 6+ Group & 6 seats \\
\hline NO Group & 7 seats \\
\hline Total & 120 seats \\
\hline
\end{tabular}

Source: Assembly of Kosovo

This government coalition is based more on the share of positions than in any systematic and profiled program. Also based on the actions, it can be concluded 
that there are non-written and silent agreements that do not interfere with one another in the ministry, despite the external appearance of functioning uniquely. AKR's condition to enter in the coalition was above all a high "price" for PAN, especially for PDK as the biggest party within ruling coalition. AKR's requests for ministerial posts were disproportionate to their power in the Parliament. Despite this, the PAN coalition accepted almost all the demands of AKR only to lead the government, offering the first deputy prime minister as well as four ministers and many deputy ministers. The same situation is with the NISMA party. Whereas AAK has only 2 ministries and also PDK has 6 ministers and the President of the Parliament. Although the government includes representatives of ethnic minorities, Serbs, Bosniak and Turks. The Turkish and Bosniak parties have two ministries. While Serbian minority have Deputy Prime Minister and three ministries. Despite privileges in the representation, due to the lack of recognition by Serbia of Kosovo's independence, Serbian representatives in Kosovo, through the 10 reserved seats in the Assembly, often, including the current government, act by conditioning their participation in the Assembly with the processes that take place in Kosovo-Serbia talks. Initially their condition for participation in Assembly and Government were with the formation of the Association of Serb Municipalities with executive powers, the refusal of the formation of the army, and finally the objection to the imposition of tariffs on Serbian goods from Kosovo. The demands of Serbs in the Kosovo Assembly and government are against the will of Albanian political parties and parties from non-majority Serb communities. This role of the Serbian parties is expected to continue until the final and legally binding agreement between Kosovo and Serbia is reached.

\begin{tabular}{|l|l|l|l|l|}
\hline \multicolumn{5}{|c|}{ Government of the Republic of Kosovo in 2017-continues } \\
\hline \multicolumn{5}{|c|}{ Political Parties in Government } \\
\hline PDK & AAK & NISMA & AKR & Minorities \\
\hline Deputy & Prime Minister & Deputy & First Deputy & Deputy Prime \\
Prime & and Two & Prime & Prime & Minister and \\
Minister & Ministers & Minister and & Minister and & Five Ministers \\
and Five & & Three & Four & \\
\hline
\end{tabular}




\begin{tabular}{|l|l|l|l|}
\hline Ministers & Ministers & Ministers & \\
\hline Total: 1 Prime Minister; 4 Deputy Prime Ministers and 19 ministers and many \\
deputy ministers
\end{tabular}

Source: Government of the Republic of Kosovo.

Such a share of positions in disproportion to their electoral power affects the quality of governance. Moreover, the non-profiled coalition is having its negative impact in the increase of the number of ministries as well as a very large number of deputy ministers.

As Farewell concludes that four of the main points, supporting the argument that PR promotes instability, are happening in Kosovo. They are as follows: 1 . PR produces coalition governments, which are unstable by virtue of being made up of several parties, and therefore governments tend to change more often. 2 . Coalition governments are not accountable, having been formed on the basis of backroom deals between party leaders after the election; the parties' manifesto promises are forgotten in the rush to gain power; the voters' wishes are ignored. 3. PR systems ensure the easy entry of small and extremist parties into parliament, threatening the stability of the government, particularly in those cases where the extremists hold the balance of power in the parliament. 4. PR systems are more complex than non-PR systems, adding an extra burden to the voters and raising the question of whether they really understand what is going on (Farell 1998, 153-154).

\section{CONCLUSIONS}

The foundation of political parties in Kosovo was influenced by political and historical circumstances, excluding the ideological model of party establishment. The party system in Kosovo due to specific circumstances, initially 'occupation' during the 1990s and then International Administration, was more oriented towards a state building than ideological profiling. The party system in Kosovo during the International Administration in terms of decision-making as well as 
the determination of the rules of functioning and the holding of elections was limited. Political parties in Kosovo 1999-2008, had limited competences because the real power were exercised by the UNMIK. Political parties in Kosovo are mono-ethnic (Albanians, Serbs, Turks, Bosnian, Roma), despite the fact that the aim of international administration was to create a multi ethnic society. Kosovo needs multiethnic parties where it will unite politicians with a vision for economic development and inclusive governance alternative even in the ethnic sense. To happen this, it seems to be early yet. Political Parties in Kosovo are dominated by leadership and clientelism more than the programs. This is imposed by the level of democratic consolidation, economic development, and the level of political culture. The party system in Kosovo needs program groupings and then the co-operation of political parties on the basis of approximate and consistent programs / ideologies. Since the first election held in 2001, no political party could win the majority because of PR electoral system with a single constituency and reserved seats for minorities. PR electoral system is producing a weak majority. This is affecting the quality of the government performance and decision-making. Thus, the negative effect both before the formation of the government and during its functioning is the lack of programmatic and ideological cooperation. Political parties in divergence with people votes and their numbers in parliament are getting privileges, while responsibility is shared. This happens for some reasons: Because of the electoral system, the lack of trust among political parties, and the lack of profiling of political parties.

There is a need for some changes in the electoral system that would guarantee a stable majority, also a better governance and stronger and firsthand citizenrepresentative links. As a first step in strengthening the citizen-representative relationship, it would be to change the electoral system by maintaining community representation through election rules. From one Multi Member Constituency (MMC), Kosovo would have to be divided into $7+1$ constituency for minorities. The designated constituency, depending on the number of voters, would representing the number of MPs. It's needed to keep threshold 5 percent in seven constituencies, where Albanian parties will compete. This would urge small parties to compete together with other parties in pre-election lists or 
would eliminate small Albanians parties to become a Parliamentary party. In 'minorities' constituency the threshold to be 1 percent. To continue with women representation by 30 percent in $7+1$ constituencies. While a special constituency $(+1)$, at Kosovo level, should be for the non-majority communities, according to the current formula $10 \mathrm{MPs}$ from the Serb community and $10 \mathrm{MPs}$ from other non-majority communities. Another change in electoral system is reducing the right to vote from 5 as it is now, in 1 candidate within the list. It will avoid the deviations of the will of the citizen as well as agreements between the candidates of the same party list to ask their electorate to vote up to five candidates, based in candidates for MP accord. This would increase the power of both, citizens and parliamentarians. This would make much more possible to have a stable government and gender representation. It would also increase the chance for a more consolidated majority in parliament, strength a coalition government, increase accountability, geographic representation and keeping representation of minorities.

\section{REFERENCES}

- ACE The Electoral Knowledge Network. 2012. "The Effect of Electoral System on Party System." Accessed 06 May 2018. https://aceproject.org/aceen/topics/pc/pcc/pcc04/pcc04c.

- Bakken, Mettr. 2008. "Electoral and Party System: Which is the Cause and which is the Consequence?" ECPR Graduate Conference in Barcelona.

- Bieber, Florian. 2008. Political Parties and Minority Participation. Skopje: FES.

- Bielasiak, Jack and Hulsey, W.John. 2013. "Party system determinants of electoral reform in post-communist states". Communist and Post-Communist Studies 46: 1-12.

- Boix, Carles and Stokes, Susan. 2007. The Oxford Handbook of Comparative Politics. Oxford: Oxford Handbooks of Political Science. 
- Brahimi, Lakhdar. 2007. "State-Building in Crisis and Post-Conflict Countries". Viena: 7th Global Forum on Reinventing Government Building Trust in Government.

- Budge, Ian and McDonald, Michael. 2007. "Election and party system effects on policy representation: Bringing time into a comparative perspective". Electoral Studies 26.

- Caplan, Robert. 2005. Europe and the Recognition of New States in Yugoslavia. New York: Cambridge University Press.

- CEC. 2018. Rezultatet perfundimtare nga QNR. Accessed 13 November 2018. http://www.kqz-ks.org/wp-content/uploads/2018/01/2.-Kandidatët-ezgjedhur-sipas-Subjekteve.pdf.

- Central Election Commision. 2017a . "CEC." Zgjedhjet në Kosovë 200-2014. Accessed $10 \quad 11, \quad 2018 . \quad$ http://www.kqz-ks.org/wpcontent/uploads/2018/02/Zgjedhjet-ne-Kosove-2000-2014_al.pdf .

- Chesterman, Simon. 2004. You, The People: The United Nations, Transitional Administration, and State-Building. New York: Oxford University Press.

- Colomer, Josep M. 2018. Party System Effects on Electoral Systems. Oxford: The Oxford Handbook of Electoral Systems. : Oxford University Press. Accessed 07 February 2019. doi:DOI:10.1093/oxfordhb/9780190258658.013.16 .

- Constitutional Court of the Republic of Kosovo. 2010. "Case, nr. KI 47/10". Prishtina.

- Constitutional Court of the Republic of Kosovo. 2014. "Case, nr. K0119/14". Prishtina.

- Constitutional Framework for provisional Self-Government in Kosovo. 2001.05.15. Kosovo Assembly. Accessed 05 September 2018. https://www.assemblykosova.org/common/docs/FrameworkPocket_EN G_Dec2002.pdf.

- Diamond, Larry. Ed. 2001. Political Parties and Democracy. Maryland: The Johns Hopkins University Press.

- Ejupi, Burim and Qavdarbasha, Shkamb. 2011. "Zgjedhjet parlamentare në Kosovë 2010." Kosovo Institute for Policy Research and Development.(04). 05-27. 
04

11.

Accessed

10.

02.

2018.

http://www.kipred.org/repository/docs/Zgjedhjet_Parlamentare_në_Kos ovë_478313.pdf.

- Ezrov, Lawrence. 2010. Linking Citizens and Parties: How Electoral Systems Matter for Political Representation. New York: Oxford University Press Inc.

- Farrell, David. 1998. Comparing Electoral Systems. London: Macmillan.

- Gazeta Shqip. 2014. “Zgjedhjet e fundit në Kosovë: KQZ shpall rezultatet përfundimtare". Accessed 06 June 2018. http://gazetashqip.com/lajme/2014/06/27/zgjedhjet-e-fundit-ne-kosove-kqz-shpallrezultatet-perfundimtare/.

- Hofmeister, Wilhelm and Grabow, Karsten. 2011. Political Parties Functions and Organisation in Democratic Societies. Konrad Adenauer Stiftung.

- Ishiyama, John. 2011. Comparative Politics Principles of Democracy and Democratization. West Sussex: John Wiley \& Sons Ltd.

- Joannin, Pascale. 2016. "General Elections in Croatia". 09 11. Accessed 30 January 2019. https://www.robert-schuman.eu/en/doc/oee/oee-1657cen.pdf.

- Judah, Tim. 2008. Kosovo, What Everyone Needs to Know. New York: Oxford University Press.

- Katz, S.Richard. 1980. A Theory of Parties and Electoral Systems. Baltimore: The Johns Hopkins University Press.

- Kosovo Assembly. 2010. "On Amending and Supplementing the Law no. 03/L-073 on General Elections in the Republic of Kosovo." Assembly. 1029. Accessed 09

October

2018. http://www.kuvendikosoves.org/common/docs/ligjet/2010-256-eng.pdf.

- Krasniqi, Albert and Shala, Krenar. 2012. "Strengthening the statehood of Kosovo through the democratization of political parties". Pristina: Kosovo Institute for Policy Research and Development. 04: 8-9.

- Krasniqi, Valon. 2016a. "Political Parties Ideologies in Kosovo." RSP 49 108119.

- Krasniqi, Valon. 2016b. "Political Parties Ideologies and State building in Kosovo". Skopje: PhD Thesis, SEEU. 
- Lewis, G.Paul. 2001. Political Parties in Post-Communist Eastern Europe. London: Routledge, Taylor \& Francis e-Library.

- Lijphart, Arend. 1999. Patterns of Democracy: Government Forms and Performance in Thirty-Six Countries. New Haven, CT: Yale University Press.

- Lindsey- Ker, James. 2009. Kosovo The Path to Contested Statehood in the Balkans. London: I.B.Tauris \& Co Ltd.

- Maor, Moshe. 1997. Political Parties and Party Systems, Comparative approaches and the British experience. London: Routledger.

- Mayer, M.Thomas and Miller, Bernhard. 2015. " The niche party concept and its measurement." Sage, Party Politics, Vol. 21(2) 259-271.

- Mershon, Carol and Shvetsova, Olga. 2013. Party System Change in Legislatures Worldwide- Moving Outside the Electoral Arena. New York: Cambridge University Press.

- Millard, Frances. 2004. Elections, Parties and Representation Post-Communist Europe. London: Palgrave, Macmillan.

- Reilly, Benjamin and Nordlund, Per. (Eds.). 2008. Political Parties in ConflictProne Societies: Regulation, Engineering and Democratic Development. Tokyo: United Nations University Press.

- Rettman, Andrew. 2018. Kosovo has right to own army, Germany and US say. Brussels, 12, 14. Accessed 10 January 2019. https://euobserver.com/foreign/143720.

- Rule, Wilma and Zimmerman, Francis, Joseph. Ed. 1994. Electoral Systems in Comperative Perspective: Their Impact on Women and Minorities. London: Greenwood Press.

- Sahadžić, Maja. 2009. "The Electoral System of Bosnia and Herzegovina: A Short Review of Political Matter and/or Technical Perplexion." Suvremene teme, 2 (1) 61-78.

- Sartori, Giovanni. 2005. Parties and Party Systems. A framework for analysis. Colchester: ECPR Press.

- Tansey, Olsey. 2009. Regime-Building: Democratization and International Administration. Oxford: Oxford University. 
- UNMIK. 2007. “Amending UNMIK Regulation 2007/26 on Election for the Assembly of Kosovo". UNMIK online. 09 07. Accessed 09 May 2018. http://www.unmikonline.org/regulations/unmikgazette/02english/E200 7regs/RE2007_28.pdf.

- UNMIK online.2001. "On Election for the Assembly of Kosovo." Regulation 2001/33. Accessed 09.2018. http://www.unmikonline.org/regulations/2001/RE\%202001-33.pdf.

- UNMIK Official Gazette.2000. "UNMIK Regulation 2000/16; 2000/21;2000/39. $\begin{array}{llll}\text { Accessed } & 10 . & 10 . & 2018 .\end{array}$ http://www.unmikonline.org/regulations/index_reg_2000.htm.

- Ware, Alan. 1996. Political Parties and Party Systems. Oxford: Oxford University Press. 